Marquette University

e-Publications@Marquette

Social and Cultural Sciences Faculty Research and

Publications

Social and Cultural Sciences, Department of

10-1-1997

\title{
Women and Gender in Middle East Studies: A Roundtable Discussion
}

Ellen Fleischmann

Middle East Report

Louise Cainkar

Marquette University, Louise.Cainkar@mu.edu

Miriam Cooke

Duke University

Susanne Dahlgren

University of Helsinki

Rhoda Kannaneh

Columbia University

See next page for additional authors

Published version. Middle East Report, No. 205, Middle East Studies Networks: The Politics of a Field, (October - December 1997): 30-32. Stable URL. (C) 1997 Middle East Research and Information Project, Inc. (MERIP). Used with permission.

Louise Cainkar was affiliated with University of Illinois - Chicago at the time of publication.

Shareable Link. Provided by the Springer Nature SharedIt content-sharing initiative. 


\section{Authors}

Ellen Fleischmann, Louise Cainkar, Miriam Cooke, Susanne Dahlgren, Rhoda Kannaneh, Akram Khater, Rosemary Sayigh, and Gabriele vom Bruck 


\section{Women and Gender in Middale East Studilies A Rountitable Discussion}

Ellen Fleischmann, an editor of this magazine, recently invited scholars who write and teach about women and gender issues in the Middle East to participate in an electronic mail roundtable discussion of the field. The questions generated very positive reactions; many people who could not participate in this roundtable for various reasons underscored the need to discuss these issues critically. In light of these responses, we treat this roundtable as part of a more engaged and inclusive discussion on the state of women and gender studies in the Middle East. The following people sent their responses in time for inclusion in this issue: Louise Cainkar, Department of Sociology, University of Illinois-Chicago; Miriam Cooke, Asian and African Languages and Literature, Duke University, North Carolina; Susanne Dahlgren, Department of Cultural Anthropology, University of Helsinki, Finland; Rhoda Kannaneh, Department of Anthropology, Columbia University, New York; Akram Khater, Department of History, North Carolina State University, Raleigh; Rosemary Sayigh, independent scholar, Beirut, Lebanon and Gabriele vom Bruck, London School of Economics, London, England. Below are excerpts of their responses.

\begin{abstract}
Should there even be such a field as "Middle East women's studies" considering the problem of compressing such heterogeneous societies and experiences into the very categories, "Middle East" and even "women?"
\end{abstract}

Sayigh The basic problem with "Middle East women studies" involves its relationship within a regional field that ipso facto cannot be theorized. Hence studies carried out within its aegis tend to replicate assumptions of a "special subject" and reinforce an absence of critical reflection on the history of Middle East women's studies. This absence has lead to repetition, implicit comparisons with Western women, rarity of innovative approaches, objectification and distancing. Awareness of the artificiality of "Middle Eastern women" as an object of study would seem to be the starting point for all of us-teachers, researchers and students. We should take the historical production of
"Middle East studies" as an object of study and criticism. We should read, and encourage students to read literature about women and gender studies in other world regions, and from other approaches.

Cainkar Who has the power to define fields? If we were powerful enough to create a field of "Middle East Women's Studies" within or across disciplines that is recognized in the academy for teaching purposes, I would be for it. I see its main purpose as creating a body of people, through teaching, who are educated on this topic, and who do not respond to media stereotypes alone. I would create a force of people who have the power to fight against mainstream (including academic) racism on the Middle East and for the interests of women in the Middle East. So, as a way to power in this society, I am for it. However, I am not for a Middle East studies research field that operates outside of the broader theories in our respective disciplines because that creates a ghetto; we are in one now and we need to get out of it.
Dahlgren The field should be called gender studies, bearing in mind that "gender" does not stand for women only, but involves both men and women. . There is a threat that the discipline builds a wall between the genders, thus cementing the actual segregation systems.

Kanaaneh The binaries of "East" versus "West," "tradition" versus "modernity" still loom large. "Tradition" is still frequently referred to as an unchanging set of "Eastern" rules and modernity still implies emancipation, advancement and westernization. What is fascinating, however, is not that this paradigm underpins many works produced outside the region, but rather that so many people from the area, men and women, including feminists, have enthusiastically adopted it. This binary remains intact for many Islamists and romantic traditionalists, who reverse the valuation but hardly question the premise. Eurocentrism is not only "them" talking about "us," or an insensitive "outsider's" view. Thus, for example, literature produced in Palestine by Palestinians is sometimes more eurocentric and stereotyping than much writing by non-Palestinians. Ironically, the criticism of "outsider" scholars seems to have placed Palestinians above racism or eurocentrism. The dynamics of this situation in which Orientalism has been embraced in the putative Orient is very interesting -if troublingand is worthy of more attention.

What of "MiddleEast exceptionalism?" Does the Middle East require specific theorizing?

Cainkar I am against specific theorizing for the Middle East. Refinements of broader theories so that they are inclusive of the lives of Middle Eastern women is crucial. Others who work on other world areas must then take those refinements into account. They won't if they don't read our work. This points to the need for 


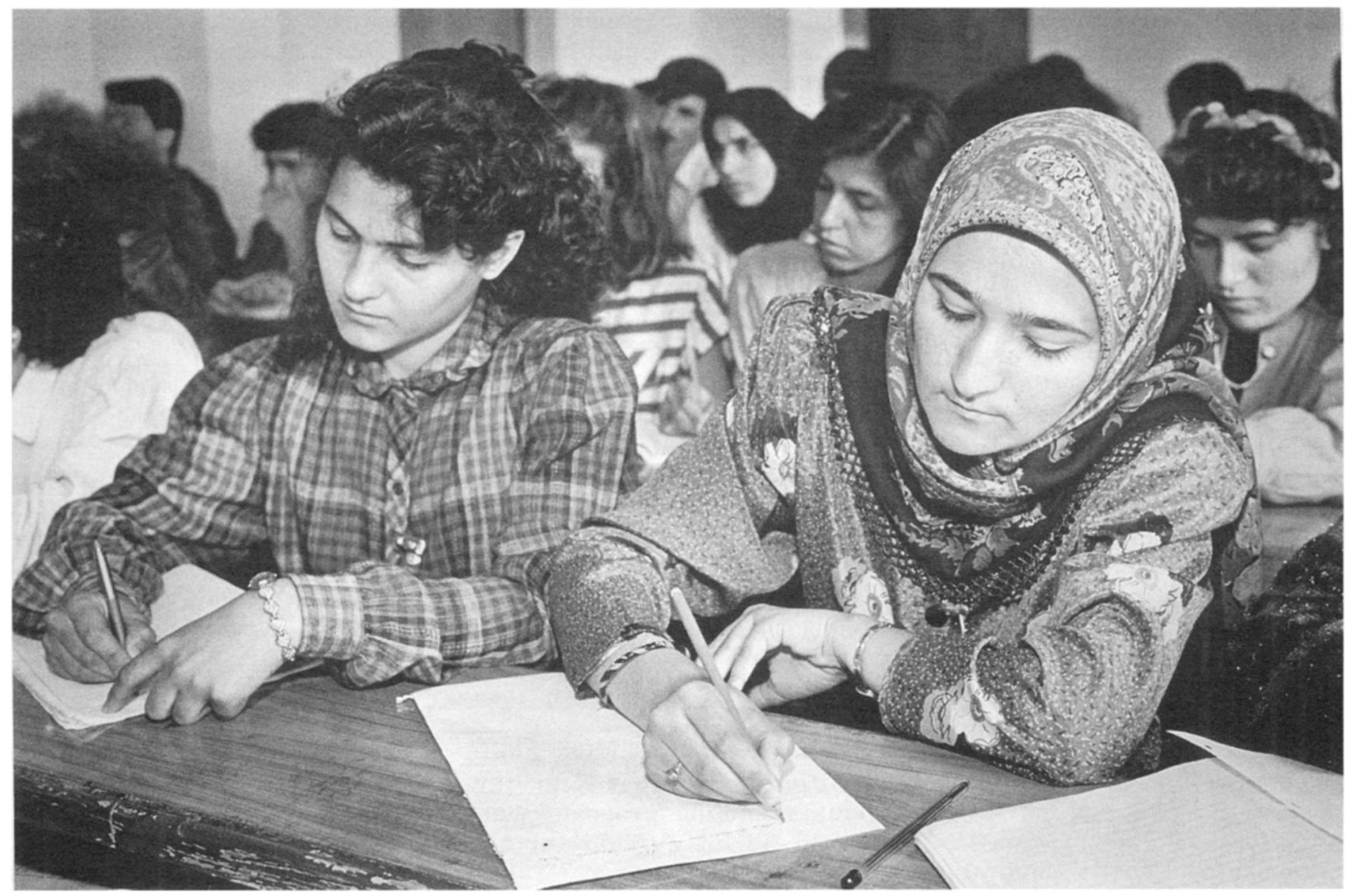

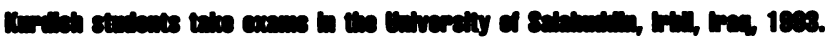

Brenda Prince//mpact Visuals

us to work on establishing cross-national or cross-regional conferences and panels. Others may not see the need to do this since their areas have some power within themselves. We must take the lead.

Cooke I believe deeply in learning from other experiences and ideologies. Western feminism is not a seamless whole that can be so easily embraced or rejected. Western feminisms are legion, and today the issues surrounding race, class and ethnicity in an America that is becoming increasingly aware of itself as multicultural are very helpful in understanding difference and diversity elsewhere.

Khater While there is nothing wrong in testing theories formulated in other fields than our own, far too often-and except for rare instances-we try to squeeze Middle
East historical experiences into frameworks constructed out of a different historical experience. I do not mean to imply that we cannot categorically learn from other fields. Rather, I think it is important to approach those fields critically. For example, I have yet to learn of a peasant who wakes up in the morning and decides to act "anthropologically" or "politically." Rather, each action is derived out of a matrix of social, economic, cultural and political elements that are in constant flux. In this sense we should reach out to each other across disciplinary divides to help see the fluctuations of this matrix. Another problem that we have not been able to circumvent-again, except for a few scholars-is applying a comparative study approach. We need to reach out to [other fields] to examine our field from outside and inside. This will help us go beyond the "exceptionalism" trap which has reduced the Middle East to a few static Weberian ideal types of Islam, veil, violence, oil, and so on. Interdisciplinary approaches allow going beyond the narrow and artificial confines into which we place our subjects.

How should we deal with the sensitive issue of authority and who produces knowledge about "Middle Eastern women?"

Sayigh We should find ways to make women part of the ontology of our research process. Constructed from the outside, "Middle East" or "Arab" or "Palestinian women" have been absent from research decisions, trapped in an 'object position.' Studies conceived in their absence may enable them to speak through the researcher, but only on topics already chosen for 
them, predefined-trauma, national mobilization, the family, whateverafter these have been negotiated between individual researchers and supervisor/institutions. My own current research interest, Palestinian women's life stories, recollections, and testimonials framed in the experience of multiple displacement, puts me in the dock. I too am guilty of taking "women" and "Palestinian" as self-evident categories and of assuming a common understanding of their meaning and "boundaries." That my purpose is political, to help form a national women's archive as the basis for future struggle for rights, may not be a sufficient alibi, at least not theoretically. I'm trying to complicate the idea of "Palestinian" as not a selfevident, quasi-biological category but as problematic, so that women must construct "Palestinianness" (or escape from it); and to problematize the idea of "women" by admitting into research the process through which "women" are produced.

vom Bruck In our theoretical accounts, we should let women speak for themselves as much as possible. I sometimes feel it is almost a taboo to write that women approve of the veil and that their husbands are unable to convince them to abandon it. For example, some Yemeni women feel they control men's sexual images through camouflaging their bodies, a notion that is anathema to Western feminists.

What topics have been neglected and need further research?

Kannaneh Much writing on gender in the Middle East fails to address many of the rapid changes that have been taking place such as consumerism and the huge impact this has had on gender relations, the female versus male body, gendered concepts of leisure work and fun, etc. This reluctance to engage such major changes perhaps lies in the fact that they make the field seem less exotic, but also because they make simple theories of resistance and power defunct.

In what area have we made significant progress, and how should we define "progress? What should be an agenda for the future?

Khater While there is lip service given to the field of women's studies within Middle East studies, the fact is, we do not have much support. I fear that this field is being marginalized rather than integrated. A way to get around this is to ask questions that naturally situate women at the center of larger issues; we have to write in a comparative way within the field of gender. How do women experience nationalism and how do their experiences define that movement are some of the new questions scholars are asking. These kinds of connections will be instrumental in making "women" part of the "central" debates within Middle East studies.

Kannaneh I think it is important to look beyond academe. If mainstream media continue to print stereotyping and sensationalist articles, and indeed they do, then we have not come very far. On October 18, 1997 the New York Times published such an article, "Women Marked for Death, By Their Own Families," on Pakistani girls in England threatened with death by their fathers and brothers because they trespassed rigid "ancient social customs." Such stories are still acceptable to, even highly sought after by, American readers and viewers. To challenge such stories, activism, "outreach" and wider appeal beyond academia are essential.

Cainkar Progress is having your work read, cited and used by researchers not interested in the Middle East. Progress is becoming a power against anti-Arab/anti-Muslim racism.

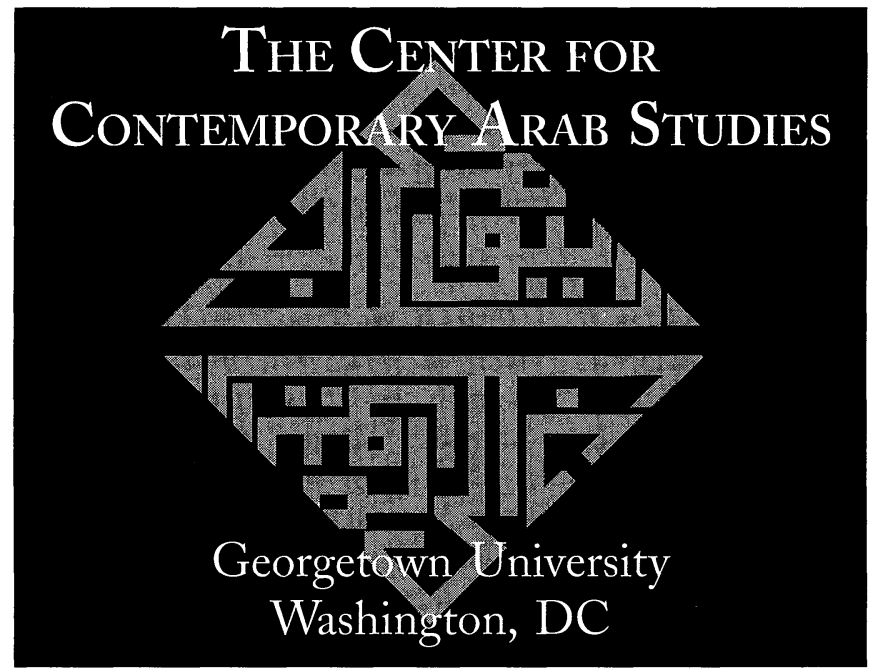

ounded in 1975, CCAS is dedicated

to preparing students for private or pub-

lic sector careers in Arab affairs and to

increasing public awareness of the re-

gion with programs in public affairs,

community outreach, and publications.

http: //www.georgetown.edu/sfs/programs/ccas 